\title{
Processing Effect on Phytase in Selected Indian Wheat Varieties (Triticum aestivum L.)
}

\author{
Manish Kumar ${ }^{1,2^{*}}$ and Sushma ${ }^{2}$ \\ ${ }^{1}$ Department of Biochemistry, Institute of Life Science, Bundelkhand University, \\ Jhansi-284128, India \\ ${ }^{2}$ Department of Biochemistry and Biochemical Engineering, Jacob Institute of Biotechnology \\ and Bioengineering, Sam Higginbottom University of Agriculture, Technology \& Sciences, \\ Prayagraj-211007, India \\ *Corresponding author
}

\section{Keywords}

phytase, wheat, germination, soaking, kilning, roasting

Article Info

\section{Accepted:}

15 June 2021

Available Online:

10 July 2021

\section{A B S T R A C T}

The effect of different process on phytase activity in four wheat varieties DBW-17, HD-2894, HUW-234 and LOK-1were evaluated. Interestingly, maximum phytase activity was observed in LOK-1 wheat variety in all the five different process i.e. $2675.44 \pm 0.56 \mathrm{nM} / \mathrm{min} / \mathrm{g} 10^{\text {th }}$ day of germination, $771.07 \pm 0.58 \mathrm{nM} / \mathrm{min} / \mathrm{g} 3^{\text {rd }}$ day of soaking, $373.77 \pm 0.62 \mathrm{nM} / \mathrm{min} / \mathrm{g} 6^{\text {th }}$ day of kilning, $342.38 \pm 0.33 \mathrm{nM} / \mathrm{min} / \mathrm{g}$ in grinding as coarse flour and $9.37 \pm 0.37 \mathrm{nM} / \mathrm{min} / \mathrm{g}$ at $90^{\circ} \mathrm{C}$ in roasting, respectively.

\section{Introduction}

The main source of world's food energy contains significant amounts of proteins, minerals and vitamins, which are essential nutrients for human health (Piironen et al., 2009). However, their absorption in humans is significantly inhibited by the presence of substances such as phytate. This is the primary storage form of phosphorus in seeds upto $85 \%$ of total seed phosphorus. The negatively charged phosphates in phytate bind strongly to metallic cations such as potassium, magnesium and iron at physiological $\mathrm{pH}$ to form a mixed salt called phytin or phytate, which reduces bioavailability to humans (Greiner and Konietzny, 2006). Soaking is a pre-treatment to enhance processing of seeds. In household activities, cereals and pulses are typically soaked in water at room temperatures overnight for consumption (Sandberg, 1991). Germination is used to breakdown antinutrients in seed such as phytate and protease inhibitors, which helps in significant increase in mineral uptake after 6 to 10 days of germination. Phytate is hydrolyzed during germination. Whereas, in non-germinated grains and cereals, only little intrinsic phytatedegrading activity is found (Egli et al., 2002). Malting is a process during which the whole 
grain is soaked and then germinated. Otherwise, if malted grains of wheat, rye and oats were used as such there was only slightly or not at all reduction of phytate content. Oat germination requires 5 days at $11^{0} \mathrm{C}$ followed by incubation at $37-40^{\circ} \mathrm{C}$, then phytate content of oats was reduced by $98 \%$ (Larsson and Sandberg, 1992). Roasting can improve protein digestibility but has little or no effect during preparation (Nout, 1993) as well as this is an important unit operation in processing of grain for making sattu due to its significant effect on the odour in the final product which is the most desired quality of sattu (Mridula et al., 2008). Milling process defines the chemical composition of any flour. Flours with higher extract ion contain increasing amount of bran. Nowadays, as consumption of whole grain breads are increased so it would be beneficial and attractive to improve the mineral status and nutrition (Turk et al., 1996).

\section{Materials and Methods}

Four locally available wheat varieties were purchased from Alopibagh market, Prayagraj, India that is namely DBW-17, HD-2894, HUW-234 and LOK-1. For experiment purpose, native of all the four wheat varieties as well as processed seeds i.e. soaked (overnight), germinated (after overnight soaking kept for 10 days), kilned (after overnight soaking, kept for 7 days and 2 hrs air dry at $\left.40^{\circ} \mathrm{C}\right)$, heated $\left(30^{\circ} \mathrm{C}\right.$ heating) and ground seeds were used for sample preparations.

\section{Phytase assay}

$0.5 \mathrm{~g}$ fresh samples of all wheat varieties were separately homogenized in $10 \mathrm{ml}$ of sodium acetate buffer (0.1M, pH 5.0). The homogenized samples were centrifuged at $12000 \mathrm{~g}$ for $5 \mathrm{~min}$ and supernatants were used for enzyme assay (Senna et al., 2006). The assay mixture consisted of $350 \mu 1$ of sodium acetate buffer $(0.1 \mathrm{M}, \mathrm{pH} 5.0)$ and $100 \mu \mathrm{l}$ of sodium phytate $(2 \mathrm{mM})$. This mixture was preincubated for $10 \mathrm{~min}$ at $40^{\circ} \mathrm{C}$ and the enzymatic reactions were started by adding $100 \mu 1$ of the crude enzyme to preincubated assay mixture. After incubation at $40^{\circ} \mathrm{C}$ for $30 \mathrm{~min}$, the liberated phosphate was measured by using the ammonium molybdate. For this, to the assay mixture, $1.5 \mathrm{ml}$ of a freshly prepared solution of acetone $/ 5 \mathrm{~N} \mathrm{H}_{2} \mathrm{SO}_{4} / 10 \mathrm{mM}$ ammonium molybdate $(2: 1: 1 \mathrm{v} / \mathrm{v} / \mathrm{w})$ and $100 \mu \mathrm{l}$ of $1.0 \mathrm{M}$ citric acid were added. Any cloudiness was removed by centrifugation to measurement of the absorbance at $355 \mathrm{~nm}$ against blank as ammonium molybdate solution (Heinonen and Lahti, 1981).The data were analyzed by SPSS ver. 20.0, two-way analysis of variance (ANOVA) at 5\% level of significance

\section{Results and Discussion}

The data pertaining to phytase assay four wheat varieties through different processing germination, soaking, heating, kilning and grinding are presented under present study. Effect of germination on phytase activity was studied at $5^{\text {th }}, 10^{\text {th }}$ and $15^{\text {th }}$ day of germination of four wheat varieties from Fig. 2. On $5^{\text {th }}$ day of germination, maximum phytase activity $(\mathrm{nM} / \mathrm{min} / \mathrm{g})$ was observed in LOK-1 $(2342.13 \pm 0.52)$ followed by DBW-17 (2065.78 \pm 0.390$), \quad$ HD-2894 (2133.51 \pm 0.46$)$ and HUW-234 (2041.17 \pm 0.66$)$. On $10^{\text {th }}$ day of germination, maximum phytase activity $(\mathrm{nM} / \mathrm{min} / \mathrm{g})$ was in LOK-1 (2675.44 \pm 0.56$)$ followed by DBW-17 (2418.59 \pm 0.48$)$, HD2894 (2471.44 \pm 0.39$)$ and HUW-234 (2372.81 \pm 0.37$)$. On $15^{\text {th }}$ day of germination, maximum phytase activity $(\mathrm{nM} / \mathrm{min} / \mathrm{g})$ was in LOK-1 (2382.07 \pm 0.55$)$ followed by DBW-17

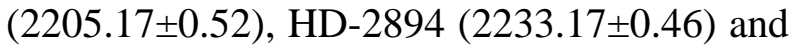
HUW-234 (2173.91 \pm 0.31$)$ Germination mobilizes reserve nutrients required for growth and development therefore may help in 
the removal of some of the unwanted compounds (Sathe and Salunkhe, 1989). Germination of seeds leads to a rapid disappearance of phytin inclusions accompanied by a large increase in activity of the phytase enzyme responsible for phytin degradation (Loewus et al., 1990). Germination triggers the enzymatic activity of sprouting grains, leading to the breakdown of proteins, carbohydrates and lipids into simpler forms. This processing method activates proteases, which are active in degrading proteins, thereby increasing nutrient bioavailability (Elkhalifa and Bernhardt, 2010).

Effect of soaking on phytase activity was studied at $1^{\text {st }}, 2^{\text {nd }}$ and $3^{\text {rd }}$ day of soaking of four wheat varieties from 3 . In $1^{\text {st }}$ day of soaking, maximum phytase activity $(\mathrm{nM} / \mathrm{min} / \mathrm{g})$ was observed in LOK-1 (734.14 \pm 0.07$)$ followed by DBW-17 (725.45 \pm 0.34$),$ HD-2894 $(730.51 \pm 0.25)$ and HUW-234 $(691.73 \pm 0.32)$. On $2^{\text {nd }}$ day of soaking, maximum phytase activity $(\mathrm{nM} / \mathrm{min} / \mathrm{g})$ was in LOK-1 $(765.24 \pm 1.45)$ followed by DBW-17 (741.06 \pm 0.24$)$, HD$2894 \quad(745.51 \pm 0.33)$ and HUW-234 (705.44 \pm 0.28$)$. On $3^{\text {rd }}$ day of soaking, maximum phytase activity $(\mathrm{nM} / \mathrm{min} / \mathrm{g})$ was in LOK-1 (771.07 \pm 0.58$)$ followed by DBW-17 (747.88 \pm 0.35$),$ HD-2894 (751.41 \pm 0.70$)$ and HUW-234 (711.37 \pm 0.32$)$. Soaking usually forms an integral part of processing methods such as germination, fermentation, cooking and toasting (Muliman and Vadiraj, 1994). Temperature and $\mathrm{pH}$ value have been shown to have a significant effect on enzymatic phytate hydrolysis during soaking. If the soaking step is carried out at temperatures between 45 to $65^{\circ} \mathrm{C}$ and $\mathrm{pH}$ values between 5.0 to 6.0 , which are close to the optimal conditions for phytate dephosphorylation by the intrinsic plant phytases, a significant percentage of phytate (26-100\%) was enzymatically hydrolyzed (Greiner and Konietzny, 1999). Effect of kilning on phytase activity was studied at $2^{\text {nd }}, 4^{\text {th }}$ and $6^{\text {th }}$ day of germination of four wheat varieties from Fig. 4. On $1^{\text {st }}$ day of kilning, maximum phytase activity (nM/min/g) was observed in LOK-1 (342.81 \pm 0.34$)$ followed by DBW-17 (323.10 \pm 0.52$)$, HD-2894 (324.70 \pm 0.35$)$ and HUW-234 (321.75 \pm 0.37$)$. On $2^{\text {nd }}$ day of kilning, maximum phytase activity $(\mathrm{nM} / \mathrm{min} / \mathrm{g})$ was in LOK-1 (352.77 \pm 0.38$)$ followed by DBW-17 (341.67 \pm 0.88$)$, HD2894 (346.04 \pm 0.58$)$ and HUW-234 $(345.71 \pm 0.29) . \quad$ On $3^{\text {rd }}$ day of kilning, maximum phytase activity $(\mathrm{nM} / \mathrm{min} / \mathrm{g})$ was in LOK-1 (373.77 \pm 0.62$)$ followed by DBW-17 $(362.34 \pm 1.21)$, HD-2894 (374.70 \pm 0.70$)$ and HUW-234 (364.71 \pm 1.29$)$.

Effect of roasting on phytase activity was studied at $30^{\circ} \mathrm{C}, 60^{\circ} \mathrm{C}$ and $90^{\circ} \mathrm{C}$ for four wheat varieties from 5 . On $30^{\circ} \mathrm{C}$ roasting, maximum phytase activity $(\mathrm{nM} / \mathrm{min} / \mathrm{g})$ was observed in LOK-1 (287.08 \pm 0.58$)$ followed by DBW-17 (281.33 \pm 0.88$),$ HD-2894 (255.13 \pm 0.47$)$ and HUW-234 (273.14 \pm 0.09$)$. On $60^{\circ} \mathrm{C}$ roasting, maximum phytase activity $(\mathrm{nM} / \mathrm{min} / \mathrm{g})$ was found in LOK-1 $(90.41 \pm 0.71)$ followed by DBW-17 (82.67 \pm 0.33$), \quad$ HD-2894 (85.67 \pm 0.33$)$ and HUW-234 (62.02 \pm 0.51$)$. On $90^{\circ} \mathrm{C}$ roasting, maximum phytase activity $(\mathrm{nM} / \mathrm{min} / \mathrm{g})$ was in LOK-1 $(9.37 \pm 0.37)$ followed by DBW-17 (8.60 \pm 0.35$)$, HD-2894 $(8.90 \pm 0.35)$ and HUW-234 (6.62 \pm 0.25$)$.

Breakfast cereal is defined as food obtained by soaking, swelling, roasting, toasting, grinding, rolling/flaking and shredding of puffing of any cereal and which is usually eaten at breakfast. Flaking is one of the methods of processing breakfast cereal, which involves cleaning, and conditioning to suitable moisture content of the whole grain and lightly rolled between smooth rolls to fracture the outer layer (Kent, 1975). 
Fig.1 Wheat native phytase

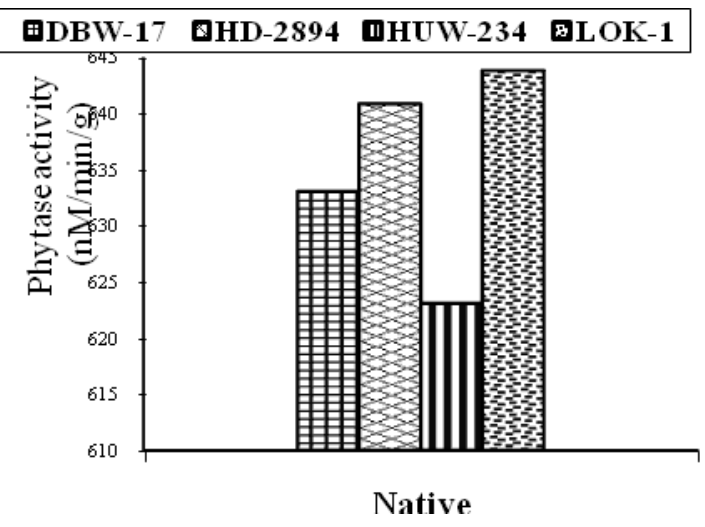

Fig.2 Effect of germination on phytase activity

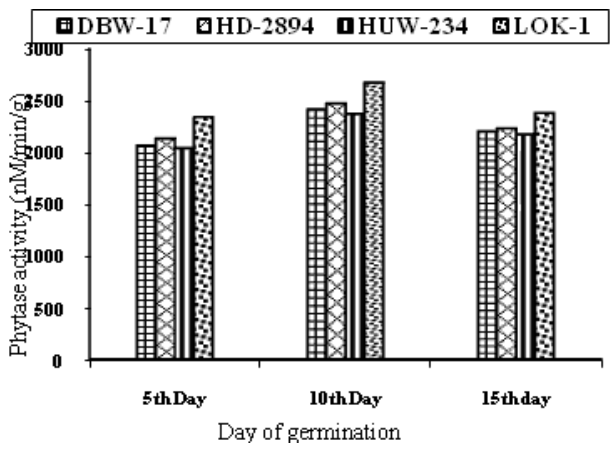

Fig.3 Effect of soaking on phytase activity

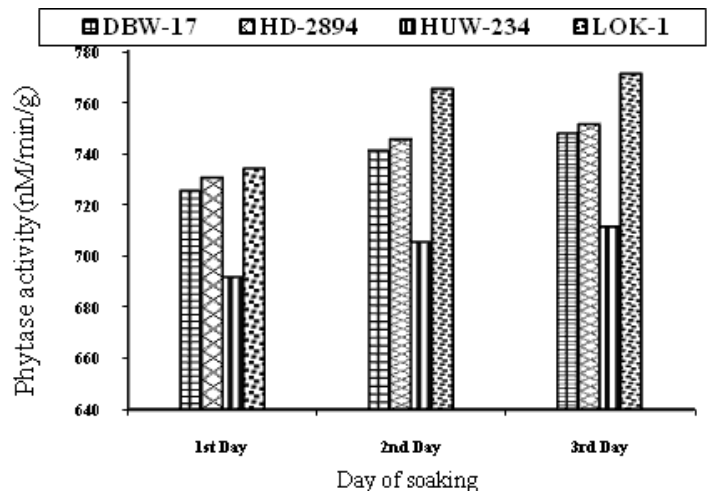

Fig.4 Effect of kilning on phytase activity

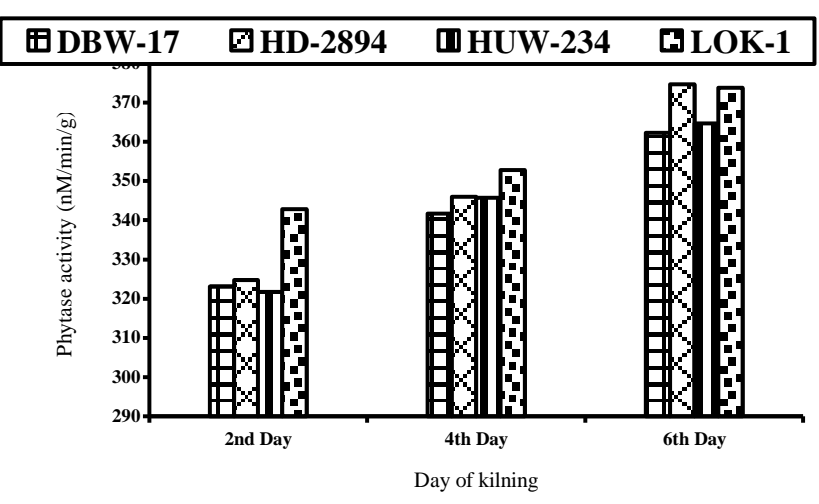

Fig.5 Effect of roasting on phytase activity

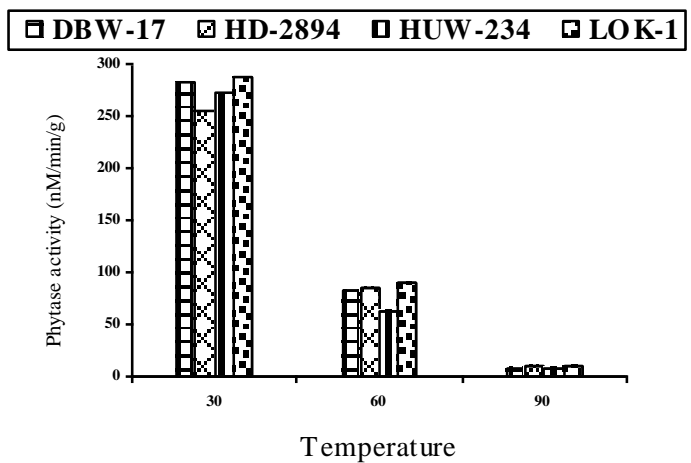

Fig.6 Effect of grinding on phytase activity

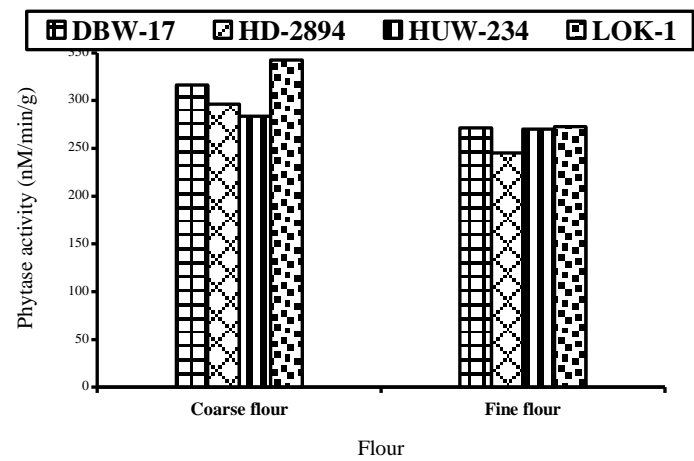


Effect of grinding on phytase activity was studied in coarse and fine flour of four wheat varieties from 6 . In coarse flour, maximum phytase activity (nM/min/g) was observed in LOK-1 (342.38 \pm 0.33$)$ followed by DBW-17 (316.15 \pm 0.18$)$, HD-2894 (295.97 \pm 0.09$)$ and HUW-234 (283.40 \pm 0.30$)$. In Fine flour, maximum phytase activity $(\mathrm{nM} / \mathrm{min} / \mathrm{g})$ was seen in LOK-1 (272.76 \pm 0.79$)$ followed by DBW-17 (271.33 \pm 0.88$), \quad$ HD-2894 (245.18 \pm 0.43$)$ and HUW-234 (269.81 \pm 0.19$)$. Grinding increased the concentration of dialyzable phosphorus, but samples that were not autoclaved. Autoclaving decreased amounts of phosphorus liberated from feed. This leads to significant part of phosphorus liberated from wheat-based feed under simulated conditions of poultry intestine may be attributed to the action of endogenous wheat enzymes (phytase and acid phosphatase). Mechanical breakdown of plant tissues improves access of those enzymes to wheat phytate (Fuller, 1991).

Similarly, $1759 \pm 73 \mathrm{nM} / \mathrm{min} / \mathrm{g}$ phytase activity in Aglika wheat variety of Bulgaria was observed by Chalova et al., (2012) but $2670 \pm 0.11$ in Roshan, $2860 \pm 0.15$ in Ghods and $3100 \pm 0.20 \mathrm{nM} / \mathrm{min} / \mathrm{g}$ phytase in Mahdavi Iranian wheat variety were reported (Sedaghati et al., 2011). A range 400 to 6000 $\mathrm{nM} / \mathrm{min} / \mathrm{g}$ phytase for oats, barley, triticale, rye and wheat was reported (Steiner et al., 2007) and 520 to $1400 \mathrm{nM} / \mathrm{min} / \mathrm{g}$ phytase in wheat was found (Cossa et al., 2000) and 710 $\mathrm{nM} / \mathrm{min} / \mathrm{g}$ phytase activity in one day seedlings of Nigerian wheat was reported (Azeke et al., 2011). Phytase exists in most cereals, but their activity varies widely among cereals (Bartnik and Szafranska, 1987). It appears that phytase activity usually increases on germination (Sung et al., 2005) and germination has been used to induce phytase activity in cereals (Senna et al., 2006). In Iranian whole wheat, $340 \mathrm{nM} / \mathrm{min} / \mathrm{g}$ phytase in Hot weather aera, 442 in Pishtaz, 490 in S-78-
11, 410 in Niknejad, 410 in Shiraz, 460 in S79-10, 370 in Keras-Adl, 450 in Chamran, 320 in Estar, 520 in Shahriar, 440 in Falat, 430 in Kavir, 430 in Marvdasht, 320 in Pavarus, 360 in Azady, 440 in Darab2, 450 in Zarin and 500 $\mathrm{nM} / \mathrm{min} / \mathrm{g}$ phytase were reported by Tavajjoh et al., (2011). In the anaphase of germination, the biosynthesis of phytase in malt of wheat decreases. In the course of germinating, variation of phytase activity presented lowhigh-low trend. In the germinating period's seeds grow only by consuming its storing matter with a low conversation rate of nutrient. Therefore, the dry matter loss is very great. The germinating condition should be optimized to gain the highest activity of phytase and the most of dry matter at the same time (Ma and Shan, 2002). The first intermediate myo-inositol was also identified as the main reaction product of $F_{1}$ phytase from wheat bran (Lim and Tate, 1973) and soybean phytase (Gibson and Ullah, 1990), which were described as 6-phytases. They are completely different from the 3-phytase or 5phytase from Aspergillus ficuum (Ullah and Phillippy, 1988) or lily pollen (Barrientos et al., 1994), respectively. Other phytases with broad substrate specificity have low specific activity for phytic acid (23 to $43 \mathrm{nM} / \mathrm{min} / \mathrm{g}$ ), whereas phytases with narrow substrate specificity generally have high specific activities of $103-811 \mathrm{nM} / \mathrm{min} / \mathrm{g}$ (Greiner et al., 1993). In soybean seed germination, a pronounced increase in phytase activity accompanies a concomitant decrease in phytic acid, with maximal phytase activity attained at approximately $10 \mathrm{~d}$ after germination (Gibson and Ullah, 1988).

The data in this study indicate that the significant differences $(\mathrm{P}<0.05)$ were obtained in the phytase activities of wheat varieties screened. The phytase activity was increased during soaking and germination but significantly decreased was observed in kilned, roasted and ground seeds. Among four 
wheat varieties, LOK-1 wheat varieties have higher phytase activity in all different process soaking, germination, kilning, roasting and grinding.

\section{Acknowledgement}

We are thankful to Head of Department of Biochemistry and Biochemical Engineering and Dean of Jacob Institute of Biotechnology and Bioengineering, Sam Higginbottom University of Agriculture, Technology \& Sciences, Prayagraj for providing all necessary facilities to conduct the experiment in research laboratory of the department.

\section{References}

Azeke, M. A., Egielewa, S. J., Eigbogbo, M. U. and Inegbenose, G. I. 2011. Effect of germination on the phytase activity, phytate and total phosphorus contents of rice (Oryza sativa), maize (Zea mays), millet (Panicum miliaceum), sorghum (Sorghum bicolor) and wheat (Triticum aestivum). Journal of Food Science and Technology, 48(6): 724729.

Bartnik, M. and Szafranska, I. 1987. Changes in phytate content and phytase activity during the germination of some cereals, Journal of Cereal Science, 5(1): 23-28.

Barrientos, L., Scott, J. J., and Murthy, P. P. N. 1994. Specificity of hydrolysis of phytic acid by alkaline phytase from lily pollen. Plant Physiology, 106(4): 1489-1495.

Chalova, V. I., Manolov, I., Nikolova, M. and Koleva, L. 2012. Effect of fertilization on phytase and acid phosphatase activities in wheat and barley cultivated in Bulgaria. Agriculture, Food and Analytical Bacteriology, 2(2): 103-110.

Cossa, J., Oloffs, K., Kluge, H., Drauschke,
W. and Jeroch, H. 2000. Variabilities of total and phytate phosphorus contents as well as phytase activity in wheat. Tropenlandwirt, 101(2): 119126.

Egli, I., Davidsson, L., Juillerat, M. A., Barclay, D. and Hurrell, R. F. 2002. The influence of soaking and germination on the phytase activity and phytic acid content of grains and seeds potentially useful for complementary feeding. Journal of Food Science, 67(9): 3484-3488.

Elkhalifa, A. O. and Bernhardt, R. 2010. Influence of grain germination on functional properties of sorghum flour. Food Chemistry, 121(2): 387-392.

Fuller, M. F. 1991. In Vitro digestions for pigs and poultry, (ed), CAB International, Wallingford.

Greiner, R. and Konietzny, U. 2006. Phytase for food application. Food Technology and Biotechnology, 44(2): 125-140.

Greiner, R. and Konietzny, U. 1999. Improving enzymatic reduction of myo-inositol phosphates with inhibitory effects on mineral absorption in black beans (Phaseolus vulgaris). Journal of Food Processing and Preservation, 23(3): 249-261.

Greiner, R., Konietzny, U. and Jany, K. D. 1993. Purification and characterization of two phytases from Escherichia coli. Archives of Biochemistry and Biophysics, 303(1): 107-113.

Gibson, D. M. and Ullah, A. B. J. 1990. Phytases and their action on phytic acid. Zn, D. J. Morre, W. F. Boss, F. A. Loewus, eds, Inositol Metabolism in Plants. Wiley-Liss, New York, pp 77-92.

Heinonen, J. K. and Lahti, R. J. 1981. A new and convenient colorimetric determination of in organic orthophosphate and its application to the assay of in organic phosphatas. 
Analytical Biochemistry, 113(2): 313317.

Kent, N. I. 1975. Breakfast cereals, Technology of cereals with special reference to wheat, $2^{\text {nd }}$ ed., Pergamon Press, Oxford, pp 213-225.

Larsson, M. and Sandberg, A. S. 1992. Phytate reduction in oats during malting. Journal of Food Science, 57(4): 994-997.

Lim, P. E. and Tate, M. E. 1973. Phytases: 2Properties of phytase fractions $F_{1}$ and $\mathrm{F}_{2}$ from wheat bran and myo-inositol phosphates produced by fraction $F_{2}$. Biochimicaet Biophysica Acta, 302(2): 316-328.

Loewus, F. A., Everard, J. D. and Young, K. A. 1990. In Inositol Metabolism in Plants, pp. 21-45, Wiley-Liss, Chichester.

Ma, X. and Shan, A. 2002. Effect of germination and heating on phytase activity in cereal seeds. AsianAustralasian Journal of Animal Sciences, 15(7): 1036-1039

Mridula, D., Goyal, R. K. and Manikantan, M. R. 2008. Effect of roasting on texture, colour and acceptability of pearl millet (Pennisetum glaucum) for making sattu. International Journal of Agricultural Research, 3(1): 61-68.

Muliman, V. H. and Vadiraj, S. 1994. Changes in trypsin and chymotrypsin inhibitory activity on soaking of sorghum (Sorghum bicolour L. Moench). Plant Foods for Human Nutrition, 46(1): 27-31.

Nout, M. J. R. 1993. Processed weaning foods for tropical climates. International Journal of Food Sciences and Nutrition, 43(4): 213-221.

Piironen, V., Lampi, A. M., Ekholm, P., Marttila, M. S. and Liukkonen, K. H. 2009. Micronutrients and phytochemicals in wheat grain. In: Khan, K., Shewry, P.R. (Eds.), Wheat
Chemistry and Technology. AACC International, Minnesota, pp. 401-435.

Sandberg, A. S. 1991. The effect of food processing on phytate hydrolysis and availability of iron and zinc. Advances in Experimental Medicine and Biology, 289: 499-508.

Senna, R., Simonina, V., Silva-Neto, M. A. C. and Fialho, E. 2006. Induction of acid phosphatase activity during germination of maize (Zea mays) seeds, Plant Physiology and Biochemistry, 44(7-9): 467-473.

Sathe, S. K. and Salunkhe, D. K. 1989. Technology of removal of unwanted components of dry legumes. In: Salunkhe, D. K. \& Kadam, S. S. (Eds) Handbook of World Food Legumes Nutritional Chemistry Processing Technology and Utilization, p. 249270. USA: CRC Press, Boca Raton, FL.

Sedaghati, M., Kadivar, M., Shahedi, M. and Soltanizadeh, N. 2011. Evaluation of the effect of fermentation, hydrothermal treatment, soda, and table salt on phytase activity and phytate content of three Iranian wheat cultivars. Journal of Agricultural Science and Technology, 13: 10651076.

Steiner, T., Mosenthin, R., Zimmermann, B., Greiner, R. and Roth, S. 2007. Distribution of phytase activity, total phosphorus and phytate phosphorus in legume seeds, cereals and cereal by products as influenced by harvest year and cultivar. Animal Feed Science Technology, 133(3-4): 320-334.

Sung, H. G., Shin, H. T., Ha, J. K., Lai, H. L., Cheng, K. J. and Lee, J. H. 2005. Effect of germination temperature on characteristics of phytase production from barley. Bioresource Technology, 96(11): 1297-1303.

Turk, M., Carlsson, N. G. and Sandberg, A. S. 
1996. Reduction in the levels of phytate during wholemeal bread making: Effect of yeast and wheat phytases. Journal of Cereal Science, 23(3): 257-264.

Tavajjoh, M., Yasrebi, J., Karimian, N. and Olama, V. 2011. Phytic acid concentration and phytic acid: zinc molar ratio in wheat cultivars and bread flours. Journal of Agricultural Science and Technology, 13: 743-755.

Ullah, A. H. J. and Phillippy, B. Q. 1988. Immobilization of Aspergillus ficuum phytase: product characterization of the bioreactor. Preparative Biochemistry, 18(4): 483-489.

\section{How to cite this article:}

Manish Kumar and Sushma. 2021. Processing Effect on Phytase in Selected Indian Wheat Varieties (Triticum aestivum L.). Int.J.Curr.Microbiol.App.Sci. 10(07): 363-370.

doi: https://doi.org/10.20546/ijcmas.2021.1007.039 